\title{
The Aesthetic of Islamic Calligraphy and Ornamentation in Prophet Mosque Interior of the Calligrapher Abdullah Zuhdi (Al-Masjid An-Nabawi)
}

\author{
Duaa Mohammed Alashari, Abd.Rahman Hamzah, Nurazmallail Marni \\ Faculty of Islamic Civilization, Universiti Teknologi Malaysia, 81310 Johor Babru, Malaysia \\ *Corresponding author:duaa1983@graduate.utm.my
}

\begin{abstract}
Article history
Received: 2019-08-01 Received in revised form: 2020-02-04 Accepted: 2020-02-05 Published online: 2020-06-30
\end{abstract}

\begin{abstract}
Islamic Calligraphy and ornamentation are using to decorate mosques as well as other sacred places all over the Islamic world. This paper provides some sources of information for understanding and studying Islamic calligraphy and ornamentation in the Prophet Mosque interior (Al-Masjid An-Nabawi). Indeed, this paper aimed to highlight the formation aesthetics of calligraphy and Islamic decorations in which the aesthetic values. There are many aesthetic values of the Islamic calligraphy and ornamentation that portrayed in the Prophet Mosque interior. The Prophet Mosque has been selected in the present research due to the uniqueness in its calligraphy and ornamentation. Abdullah Zuhdi a calligrapher who was known as the calligrapher of the two holy sanctuaries (katib al-haramayn). The calligraphy and ornamentation in the Prophet Mosques are testifying to the skill of the master calligrapher. The principles of aesthetics in calligraphy and ornamentation based precisely on the principles of the beauty of Islam. After Islam, calligraphy was one of the most important kinds of art in Islamic world as well as one of the essential features of Islamic civilization. This study aims to show the necessity of studying Islamic calligraphy used in the Prophet Mosque interior as well as to display some Quranic verses that been written above the tomb of the Prophet Muhammad. The Prophet Mosque located in Medina city in Saudi Arabia as a model simply because it was one of the first mosques built by Prophet Muhammad and it has the fantastic and historical calligraphy and ornamentation that have a long history. The study has revealed that the calligraphy and ornamentation in the Prophet Muhmmad Mosque considered as an innovative art through its dependence unique Thuluth script and intricate pattern of Islamic motifs, the Muslim artist creativity expressed about the sacred calligraphy and highlighted the global nature of the decoration.
\end{abstract}

Keywords: Islamic architecture, Arabic Calligraphy, Islamic ornamentation, Islamic art, Islamic civilization. 


\subsection{INTRODUCTION}

Islamic heritage is rich in ancient and beautiful arts. Islamic art is the world most widespread art. Islamic calligraphy and ornamentation are the most substantial arts in the Islamic world; in another word, these arts consider as the heart of Islamic art. The mosque in Islam is considered a symbol of Islamic architecture. Mosques around the world have many different styles of a structure as well as the interior and exterior design decorated with calligraphy and Islamic motifs. The Quran mentioned the role and importance of mosques in several verses. The Prophet's Mosque is the mosque in which was founded on piety, mentioned in the verse of the Quran in Surah At-Taw bah (Do not stand [for prayer] within it - ever. A mosque founded on righteousness from the first day is more worthy for you to stand in. Within it are men who love to purify themselves, and Allab loves those who purify themselves). (Surah At-Taubah: 108).

The Prophet Mosque has different styles of historical Islamic calligraphy and motifs that decorate the external and internal of the mosque. Also, the architectural design and construction of the mosque have many different styles. This mosque located in the city of Medina in the Hejaz region of Saudi Arabia. Moreover, this mosque is the most significant of sites in Islamic history. The mosque built by the Prophet Muhammad (peace and blessings be upon him). The prophet Muhammad built the mosque in $622 \mathrm{CE}$. After he died, the mosque became his home to his final resting place. The city of Medina considered as the inspiring historical birthplace of Islam. This mosque is one of the first mosques built by the prophet Muhammad. Also, this mosque considers as one of the largest mosques in the Islamic world. During Ottoman ear, the interior of the Prophet Mosque adorned with many decorations such as the geometric and organic pattern as well as with many inscriptions of the Quran designed by the Islamic calligraphers and designers.

The Prophet Mosque considered as a model of Islamic acritude simply because it was one of the first mosques built by Prophet Muhammad, and it has the fantastic and historical calligraphy and ornamentation that have a long history. Furthermore, The Prophet Mosque has a unique and famous style of Islamic art. Generally, each style in the mosque comes from a different period of government that role the city of Medina as well as the culture of the artists who re-designed the calligraphy. In the Islamic world, most mosques interior have the same noticeable structure of the fantastic Islamic calligraphy and decoration, but, they differ from each other by the kind of decoration presented on them. The research selected the Prophet Mosque (Al-Masjid An-Nabawi) for its unique historical styles of Islamic calligraphy and ornamentation that designed by the calligrapher Abdallah Zuhdi.

In the Ottoman era, The Sultan Abdul Majid started the most significant expansion for the Prophet Mosque in 1265 AH 1849 and ended in 1277 AH in 1860. This expansion lasted for about 13 years. This structure was one of the most significant expansions that had made for the Prophet's Mosque during the Ottoman era. The roof of the mosque covered with 170 domes. The domes decorated with inscriptions of the Quran. Also, Islamic calligraphy was adoring the wall of the mosque at the south by the calligrapher Zuhdi. Also, the walls covered with some Quranic verses and some names of the Prophet Muhammad. The style of handwriting used Thuluth script and painted by gold color on red and blue background. However, the distinction of the Prophet Mosque lies in the design that carries many details to present the Islamic culture and Islamic identity in traditional historical Islamic architecture.

The Prophet Mosque has aesthetic values and symbol of a religious, spiritual, and artistic method embodied in the same elements that formed inside the mosque. The study showed the importance and the value of calligraphy and ornaments units. Calligraphy is divided into six styles, while the ornaments divided into florals and geometric pattern. For instance, the Islamic Page | 70 
calligraphy can mix with a floral ornament or geometric to give the principles of unity, rhythm, symmetry, multiplicity, as well as the principle of eternity.

\subsection{THE AESTHETICS ASPECTS OF ISLAMIC CALLIGRAPHY INSIDE THE PROPHET MOSQUE}

Calligraphy is considering the heart of art in the Islamic world. The word calligraphy in Arabic means "bandast al-khatt," which means the geometry way of writing the Arabic. In the Prophet Mosque, Islamic calligraphy can found inside and outside the mosque. The art of calligraphy in the mosque is presenting in the form of a combination of Islamic motifs. All the calligraphy is surrounding by a variety of geometric and organic forms arranged in a way that is repeated and combined with another form of ornaments. Islamic calligraphy and Islamic ornaments create a form of decoration on the ceiling and the walls inside the Prophet Mosque. The subject of calligraphy used in the mosque comes from different sources of the Islamic religion. For example, most of the calligraphy that adoring the mosque is coming from words written in the Quran and words of the Prophet Muhammad known as the Hadith. Islamic calligraphy in the mosque has a beautiful harmony that formed in a combination between an inscription and ornamentation.

The Quran has been describing paradise being a beautiful place. As in the following verse; "For them will be Gardens of Eternity; beneath them, rivers will flow; they will be adorned therein with bracelets of gold, and they will wear green garments of fine silk and heavy brocade; they will recline therein on raised thrones. How good the recompense! How beautiful a couch to recline on?" From this verse, we understand the importance of decorating the Prophet's Mosque of some aesthetics feature of motifs and ornamentation, which portrayed the Paradise garden symbolically. Beauty that emerged through the manifestation of floral, geometrical motifs and Islamic Calligraphy inspired from the meaning of the verses from the Quran.

Islamic calligraphers started using Arabic calligraphy to express the aspect of spirituality in written the Quran in beautiful styles inside the Prophet Mosque to decorate the internal surface. The art of inscription and ornamentation that are decorating the Prophet Mosque describe as nonfigurative art.

Islamic calligraphy based on the aspect of aesthetic elements as well as focusing on the meaning of the verses of the Quran. In the Prophet Mosque, the calligrapher who re-designed the inscriptions in the mosque was focusing on the aesthetic elements of writing the word of God without losing the meaning of the word. Furthermore, calligrapher concerning about aesthetic aspect of calligraphy and spirituality. The present inscriptions inside the mosque with its masterly interweaving of the forms of the letters of Thuluth style testify to the skill of the calligrapher Zuhdi as well as present the spirituality and beauty of Islamic calligraphy.

Islamic calligraphy is one of the most prominent kinds of Islamic art. Calligraphers adopted inscription of written the verses of the Quran to decorate Islamic building such as mosques. In the Prophet Mosque, there are some verses from the Quran, and some Prophet names had been written on the entrances, on the walls, and on the domes used for building decoration as well as reflecting the fundamental principles of Islam. Using calligraphy to write the names of the Companions, the beautiful names of Allah, the name of Prophets and the name of Caliphs, is considering as Islamic tradition of decorating, at the same time conveying a feeling of spirituality that is presenting inside the Prophet Mosque. 
In the Prophet's Mosque, the walls and the domes inscribed with some surahs from the Quran. For example, surah Al-Anam, surah al-Kahf, surah Maryam, surah al-Muzzammil, and surah alMuddaththir. Indeed, other surahs from the Quran included surah Yasin, surah al-Duha, surah alJuma, surah al-Rahman, surah al-Shams, surah al-Lail, surah al-Mulk, surah al-Naba, surah alInshirah, surah al-Takathur, surah al-Fath, surah al-Qadr, and surah Al-Alaq. In addition to the last verses of surah al-Baqara and the first five verses of sura al-Baqara. The dome of the mosque contains some surah from the Quran, surah Surah al-Fatiha, some verses from surah al-Hujurat, surah al-Juma, surah Yasin, surah al-Qadr, surah al-Rahman, as well as surah al-Nasr, surah al-Aurand, surah al-Kawthar. All these verses and surahs written by some Turkish calligraphers, one of the remarkable calligraphers is Abdalla Zuhdi.

An excellent example of Islamic calligraphy can be found on the Qibla wall and above the tomb of the Prophet inside the mosque. Above the tomb of the Prophet, there are three of the Ayah that written from different surahs. The first verse is from surah Al-Hujurat (O you who have believed, do not raise your voices above the voice of the Prophet or be loud to him in speech like the loudness of some of you to others, lest your deeds become worthless while you perceive not (Surah Al-Hujurat, 2). The second verse is from surah Al Ahzab (Muhammad is not the father of [any] one of your men, but [he is] the Messenger of Allah and last of the prophets. And ever is Allah, of all things, Knowing (Surah, Al-Ahzab,40). The third verse is from surah Al-Hujurat (Indeed, those who lower their voices before the Messenger of Allah - they are the ones whose hearts Allah has tested for righteousness. For them are forgiveness and a great reward (Surah AlHujurat, 3). All these verses were written by Thuluth style on a green and red background by gold color. These calligraphies beatifying the wall of the Prophet tomb as well as create sanctity and spirituality.

Calligraphy styles have many different types that used to write the Arabic script. Each style of Islamic calligraphy has been developed over many years in different regions by different school and calligraphers. The Islamic calligraphy was adopting to write the verse of the Quran and other scripts to decorate the internal space of the Prophet Mosque by the calligrapher Abdalla Zahid. Zahid adapts Thuluth style in writing and re-designed most of the inscriptions inside the mosque.

The meaning of the word Thuluth in the Arabic language means the third. There are some theories that relate to the Thuluth style. One of them refers to the pen size that is used to write this style. One famous calligrapher from the Abbasi's ear called Ibn Muqlah. Ibn Muqlah says that "In Thuluth, one-third of the letters are straight, and two-thirds, are round." Moreover, in the Thuluth style, the method of writing script is distinguished by overlapped, stretched, complicated, bent, thickened, and prolonged. There are many styles used in writing calligraphy inside the Prophet Mosque, such as Kufic, Naskh, Diwani, and Thuluth, but the most style adapted to inscription calligraphy is the Thuluth style.

Thuluth style of written linked with decorating the Interior and exterior of many mosques all over the Islamic world. This style has several features, one of the inclusions of vowel signs and ornamental that are used to beautify the script. Thuluth style combines a combination of curve and straight lines. The letters of Thuluth style are large but very compact, and round shapes predominate the texture of the style.

The definition of painting is the artistic experience that is expressed in a two-dimensional plane using color and line." According to Affandi (1994), calligraphy painting is the work of man as the result of the processing of inner expression through writing elements arrangement and other two-dimensional elements, which has a symbolic nature, religious, and aesthetic and bring the ethic 
message between human and God, human and human, and human and nature. Emphasis on the messages of the beautiful setting of letters.

The Islamic calligraphy that is presenting inside the Prophet Mosque has a variety of shapes and forms. They differ in term of their features due to each style of calligraphy. Ibn Muqla is the first calligrapher who puts the principles of the Islamic calligraphy. According to the calligrapher Ibn Muqla, the basic rule of calligraphy depends on the size of dots made by the bamboo. The proportion script of Ibn Muqla is relied on the principles of geometric design of the dots to determine the aesthetic value of the Arabic Calligraphy.

In general, the aesthetic values of Islamic calligraphy are subject to several standards. For example, they are using Arabic letters to create some composition of words that convey a sense of movement through adapted different forms of calligraphy. Some of the aesthetic values of calligraphy related with, rhythm, balance, and unity between letters and words and words and the overall of the composition of the work. The alphabets of Arabic calligraphy are an element of decoration and contains movement, mass, and rhythm. The most prominent aesthetic characteristics of the Arabic calligraphy is the straightness and harmonious of letters.

The Islamic calligraphy that adorns the Prophet Mosque is considering as one of the most critical aesthetic arts in which the linear formations of compositions have different designs and colors. These calligraphy arts embodied in harmonious and intertwined forms. The harmony, intertwining, and the interplay between letters and words are one of the essential rules of beauty in calligraphy. The line is not just an ornament for writing but a search in which the calligraphers seeks to release the words and the letters for expressing the movement of rhythmic harmony that calligraphy art contains. Moreover, Islamic calligraphy is an art that has a wide range of aesthetic values.

Islamic calligraphy is an elegant art that is expressing the combining of spiritual meaning with the aesthetic beauty of the Arabic language. The art of Islamic calligraphy inside the Prophet Mosque is considering as a fundamental decorative element. Islamic calligraphy and ornamental designs have been widely used throughout ancient and modern times to decorate mosques all over the Islamic world. All Muslims heart and soul linked to the surrounded beauty inscription of Quran, that written on the walls and the domes inside the Prophet Mosque. The traditional calligraphy considers as the central sacred art of Islam that is a gift from God. The Islamic calligrapher overlays some of the surface of the wall of the mosque with an intricate variety of calligraphy and ornament patterns in delicate fancy, leaving behind a cultural and artistic legacy of Islamic art.

\subsection{THE PRINCIPLE OF ISLAMIC ORNAMENTATION INSIDE THE PROPHET MOSQUE}

The ornamentation in Islamic art has the creativity of patterns and shapes. The concept of decoration in Islamic art depends on nature. Nature has a rich of shapes and size by taking something from nature and transforming to a new shape and form. According to Grabar (1983), before going deeper into specific ornamentation in Islamic art, it is essential to classify the transformations in visual forms from the religion understanding and opinion. The classification will be the evidence of civilization with some communal symbolism or motifs in the ornamentation and the yardstick in measuring the technology level of the Muslim community around the globe. 
The Ornamentation in the prophet mosque has a variety and unity because Islamic art explains unity and diversity. Moratada (2003) states that "One of the motives of traditional Islamic buildings is to make the life of believers and users correspond to their built environment, thus inter-relate strongly and harmoniously." From this quote, we can be understanding how the ornamentation inside the Prophet Mosque gives a strong feeling of spirituality and harmony.

In Islamic art, geometry creates basic patterns of a uniquely different design. In the Prophet Mosque, the Islamic motifs and ornaments have characteristic of the infinity of geometric and organic patterns. Indeed, the intricate geometric and organic patterns are presenting the infinity of Allah the Almighty.

What makes this ornamentation special is the interlacing lines weaved carrying various patterns showing the most fantastic imagination and inventiveness (Baer, 1998). There is multiplication of geometric pattern intricate with the architectural element. Islamic patterns represent a combination of motifs comes in floral or vegetal figures. According to Haider (1996), faith means to accept all the ideas that attribute Islamic parameter without demanding any strict evidence. The main reason for having ornamentation, especially in mosques is to feel the existence of Allah the Almighty. The feelings derived in striving to be closer to Allah.

According to Al-Ghazali, saying that "God is beautiful and loves beauty" (a Hadith of the Prophet Muhammad in Sahih Muslim 1.93:91.), secondly everything in the universe is created by God, and those things will reflect God's majesty and beauty. Therefore, men as one of God's creation must lead their life, revealing God's way of guiding us (Wijdan, 2001).

Islamic artistic expression has many principles of design. For example, the floral design, Arabic calligraphy, and geometric pattern are considering the principles that express the idea of Islamic art. The tradition of multiple-level floral designs reached maturity during the fourteenth century (Bonner, 2003). There are two types of Islamic decoration that are decorating the surface inside the Prophet Mosque. The first type is the floral decorations. Floral decorations or motifs based on the branches of the plant, leaves, and flowers, then it is drawn away from its natural origin to abstract form based on the original shape of nature. The second type is engineering or geometrical decoration. The engineering decoration based on geometric shapes such as circle, square, and rectangle, and from these geometric shapes, the artist creates interlocking lines and stellar. Islamic ornamentation is presenting forms of artistic and beautiful lines that express the depth and beauty of Islamic art.

According to Burckhardt (1967), The Islamic ornaments has rhythmic, mathematical and melodious, and this is most significant for the spirit of Islam in its equilibrium of love and intellectual sobriety. The variety of shape and colors of geometrical and organical patterns add an aesthetic value to the surface of the external and internal of the mosque. Geometrical motifs explore the pattern of symmetry. Abas (1995) states that "The harmony of the Universe can only truly be experienced in the purest perfections of geometrical form."

The surfaces of external and internal of the Prophet Mosque have a striking mix of a variety of color pattern and decorative density. The organic and geometric patterns are incorporated of repetitive pattern design by geometric shapes. The density of Islamic decorations and motifs are wonderfully oriented and harmonious. All these ornaments that are decorating the surfaces of the Prophet Mosque are suggesting how the artist gives their royalty to create the distinguish Islamic ornaments and motifs. 
In the Islamic world during the fifteenth century, the techniques to create this geometric pattern reached maturity. The historical path of Islamic geometric patterns developed from many regions. Some geometric patterns come from Persia and Transoxiana. On the other hand, some of the geometric patterns come from Morocco and Andalusia. The methods used to create multiple geometric patterns developed in both regions. Islamic geometric patterns represent the last great outpouring of inspired creativity in the long and illustrious history of Islamic geometric pattern making (Bonner, 2003).

Flor ornaments are resemblance from nature with rhythm and repetition. This kind of ornament based on leaf and flower were combined with branches but in a unique creative method. In floral design, the plant was used to form it in a method that stylistically distinct and different with multiple levels (Bonner, 2003). Floral ornaments are famous in decorating mosques and Islamic buildings. In the Prophet Mosque, there is a combination of floral and geometric motifs. Floral ornaments are playing an important role to decorate the surfaces of the mosque.

The most crucial principle of ornamentation is unity, eternity, abstraction, rhythm, and symmetry. The principle of unity conveys through the type of geometrical stars. Because these stars consider the most striking symbol of the contemplative state of mind, which conceives "unity in multiplicity and multiplicity in unity" (Burckhardt, 1967). Moreover, ornamenting concept represents the principle of eternity by drawing the idea that God is eternal. It is an indefinite existence without a start or a finish (Baer, 1998).

The principle of abstraction in ornamentation is based on the way of art which is depending on objects to depicted but in a new way of represented differently. Another principle is the principle of rhythm. An example, of this principle, presents using circles to create the work of art with a rhythmical repetition, different arrangements to form at the connection points.

Other principles of Islamic decoration are symmetry - symmetrical arrangements of Islamic ornamentation used in decorating Islamic buildings. The decoration inside the Prophet Mosque involves the use of floral motifs, geometric shapes, and written script together. An example of symmetry happens if the section of the structure were vertically divided into two pieces from the middle; the ornament on each piece would be similar (Etikan 2011).

Ornamentation in the Prophet mosque is testifying much diverse art that incorporated with the architectural statement of the building. Ornamentation art is depending on principles and ideology of Islam. Also, this art considered as a sacred art. Indeed, this art is borne out through contemplation and thinking of God as recommended in the Islamic religion. Also, artists create this unique kind of art by contemplative on nature. The spiritual function of ornamentation art could not be performing if they were not related to this art to the most intimate manner to the Islamic revelation (Hossein, 1987).

\subsection{THE ARTISTIC AND SUBJECTIVE BIOGRAPHY OF THE CALLIGRAPHER ABDULLAH ZUHDI}

Abdullah Zuhdi is known as the Calligrapher of the Prophet Muhammad. His full name is Abdullah Zuhdi Effendi Nabulsi. Zuhdi is known as the "Calligrapher of the Custodian of the Two Holy Mosques and the calligrapher of Egypt." Zuhdi descent relates to the companion of the Galilee Tamim bin Aws al-Dari. Zuhdi artwork found in the Prophet's Mosque and the Mosque of Umm Abbas in Cairo. He was born in Nablus in 1251 AH / 1836 AD and in the same year emigrated with his 
father and grandparents from Nablus to Damascus. Then they emigrated to the city of Istanbul in Turkey in $1251 \mathrm{AH} / 1836$.

Abdullah Zahid was a young man of twenty-four years of age when he moved with his family to live in Istanbul, the capital of the Ottoman empire. Zahid started learning Arabic calligraphy at an early age. He was learning and studying from past famous calligraphers who establish the role of Arabic calligraphy. Also, Zuhdi studied calligraphy under the calligrapher Rashid Afendiand the calligrapher Mustafa Ezzat Effendi. He learned from them the writing of the Thuluth and Naskh styles. When he mastered writing calligraphy, he developed his unique style of writing. After that, he appointed as a teacher of painting and calligraphy at Noor Ottoman University.

Sultan Abdul Majid in 1839 set a large budget for reconstruction and expansion of the Prophet's Mosque. The Sultan worked hard to have a level of care and attention for beautification the Mosque of Prophet in Medina city. The Sultan Abdul Majid accomplished Islamic calligrapher for adorning the mosque with calligraphic inscriptions and Islamic motifs. This calligrapher was Abdullah Zuhdi. Zuhdi was chosen by the senior calligraphers despite his young age to go to Medina in 1270 AH / 1853-1854. He wrote a collection of Quranic verses and some of the noble prophetic traditions as well as some poems that said in praise of the Messenger of Allah peace be upon him.

Abdullah Zuhdi spends many years of his life living in Medina the city of the Messenger Muhammad adorning the mosque with some of the most exquisite calligraphy ever had written before. The famous masterpiece of his art was on the long stretch of the wall on route to the Prophetic tomb. This wall adorned with verses from the Quran as well as some of the Prophet names. Indeed, the calligraphy art that appears on this wall is unique panels that are describing various sections of the mosque.

The dome painted green color, and this color remained until this day. The Sultan Abdul Majid II between 1848 and 1860 did one of the most significant major restoration and expansions for prophet mosque. As part of the renovation work to prophet mosque, the well-known calligrapher Abdulla Zahid was sent to Madinah to do the work. Zuhid spent three years adoring domes and walls with Arabic calligraphy. The calligraphy work included Quranic verses, poetry, and the numerous names and titles of the Prophet Muhammad names.

After Zuhdi finished his work of adoring the Prophet's Mosque with Arabic calligraphy, he returned to Turkey. In $1283 \mathrm{AH} / 1866$ AD Zuhdi went to Egypt. His reputation preceded him as the writer of the Two Holy Mosques. He received by Khedive of Egypt Ismail Pasha and was called the first calligrapher of Egypt. At Egypt, he did some tasks of writing lines on the mosques, schools and other architectural facilities that were built in that era, as well as writing the Quranic verses on the cover of the Kaaba. Besides, he taught the art of calligraphy in the Khedive school, and he graduated with many calligraphers.

Calligraphy lines of Abdullah Zuhdi characterized by several technical features. He is fluent in the art of drawing as well as the art of creating a linear composition. One of his features in writing calligraphy is the straight lines. Zuhdi artwork is famous for harmony and proportionality. Abdullah Al-Zuhdi mastered many techniques such as drawing, engraving on stone, and marble. He was able to write calligraphy by using different materials on different surfaces. Abdullah Zuhdi he is a genius artist who contributed to the development of Arabic calligraphy

Zahid resettled in Cairo and been adorning various mosques with his spiritual art. Zuhdi, after a full life of work, became a flag of the Arabic calligraphy. He died in 1279 AH / 1879 AD. 
He was buried in Cairo in the tombs of Imam Shafi'i, precisely behind the Dome of the Imam Wakey. Zuhdi artwork in the prophet Mosque interior considered as a most significant example of Islamic calligraphy that was produced by an Ottoman genius calligrapher. Also, his artwork remains as a source of inspiration and beauty for other calligraphers. Abdullah Zuhdi is a master calligrapher who was known as katib al-haramayn and was famous for the re-design of the inscriptions that are adoring the surface inside the Prophet's Mosque in Medina.

\subsection{CONCLUSION}

The Prophet Mosque is considered the holiest mosque in the Islamic world. Also, this mosque is a symbol of Islamic architecture that presents many styles of unique Islamic art. Also, this mosque is playing a significant role that reflects the superiority of God. The Islamic calligraphy and ornamentation inside the Prophet Mosque present the highest quality of aesthetic value. The internal space in the Prophet Mosque displays beautiful examples of calligraphy and Islamic decoration that fulfills the psychological needs of human beings.

The art of Islamic calligraphy is one of the most sacred kind of art that has a spiritual dimension and relates to adorning mosques all over the world. Moreover, Islamic calligraphy has a universal spirituality. The calligrapher Abdullah Zuhdi has been using Arabic calligraphy as a visual language focused on its spiritual and aesthetic aspect to adorn the internal space of the Prophet Mosque.

The Islamic calligraphy inside the Prophet Muhammad Mosque appears in conjunction with geometric, organic patterns and motifs. Moreover, ornamentation considers as part of mosque components of the Prophet Mosque architecture. The ornamentation that is adoring the internal space of the mosque has to testify diverse artistic incorporated in the architectural statement of the building. Ornamentation art is depending on principles and ideology of Islam.

The aesthetic aspects of calligraphy and ornamentation inside the Prophet Mosque are expressing the significance of timelessness with a marked sense of rhythm, repetitions, and decorative patterns. The abstract nature of the ornamentation designs is more significant than the material aspect. The complexity of Arabic calligraphy and ornamentation is created to hold the worshiper's attention.

Furthermore, the aesthetic aspects of Islamic calligraphy and Islamic ornamentation are movement, rhythm, and dynamism that is representing through the intricate lines. The aesthetic principle of calligraphy work and Islamic ornamentation demonstrate the beauty of Islamic art. Indeed, Islamic art associated with the Islamic religion. Also, Islamic art demonstrates the simplicity and complexity of Islamic civilization.

Islamic calligraphy and ornamentation express the repetition, unity, rhythm, variety, and balance behind the work of art. Moreover, the central aspect of adorning the Prophet Mosque by calligraphy and motifs is to deliver a sense of universal spirituality. Another aspect is for meditation on the meaning behind the sacred verse of the Quran.

The Islamic calligraphy and the ornamentation inside the Prophet Mosque are one of the most beautiful work of art in the world done by the master calligrapher Zahid. This art distinguished by its uniqueness of Islamic art. Indeed Islamic calligraphy and ornamentation that are presenting inside the Prophet Mosque have great cultural material and a variety of styles. The calligraphy inside the mosque shows the variety, creativity, and unique form of Arabic scripts and traditional Islamic color. The calligrapher Zahid reached the most beautiful shape of the Arabic language by using the Thuluth style.

Page | 77 
The Prophet Mosque is notable for its vast interior space that adoring with great, glories and historical calligraphy and ornamentation. The art of calligraphy interpreted as "spiritual mathematics materialized and developed by application of calligraphic equipment" (Telarc, 2013). Islamic calligraphy and Islamic ornamentation convey the spirituality and quintessential message of Islam throughout the language and motif. Islamic calligraphy and ornamentation have a glorious artistic heritage.

\section{List of Reference}

Al-Quran

Afifi, F. S. (1992). “Al-Khet al-Thulth” [Thuluth script]. Egypt: Usamah li al- Nashr wa al Tauzi.

Afifi, F. S. (1990). “Al-Kitabah al-Muta akisah” [The Mirrored Image script]. Egypt: Maktabah Mamduh.

Ali, Wijdan, Suhail Bisharat (1989). Contemporary Art from the Islamic World. London: Scorpion Pub., on behalf of the Royal Society of Fine Arts, Amman.

Abas S., Salman A. (1995), Symmetries of Islamic Geometrical Patterns, World scientific publishing Co. Pte. Ltd, Singapore.

Blair, Sheila. (2006). Islamic Calligraphy. Edinburgh: Edinburgh University Press.

Brend, Barbara. (1991). Islamic Art. Cambridge, Mass: Harvard University Press.

Bloom, Jonathan, and Sheila Blair. (2011). And Diverse are Their Bues: Color in Islamic Art and Culture. New Haven [Conn.]: Yale University Press.

Bonner Jay (2003), Three Traditions of Self-Similarity in fourteenth and Fifteenth Century Islamic Geometric Ornament, Meeting Alhambra, Isama- Bridges Conference Proceedings, 1-12

Blair, S., \& Bloom, J. (2017). By the pen and what they write: Writing in Islamic art.

Blankenship, Sherry. (2003) "Cultural Considerations: Arabic Calligrapby and Latin Typography." Design Issues 19(2,) 60-63.

Baer, Eva (1998) Islamic Ornament. New York University Press

Burckhardt Titus (1967), Perennial Values in Islamic Art: Studies in Comparative Religion, 1(3), 102. World Wisdom Inc.

Dutton, Yasin. (2007). Islamic calligraphy. Bulletin of the School of Oriental and African Studies, University of London, 70(2), 421-423.

Derman, M. U. (1998). "Letters in Gold: Ottoman Calligraphy from the Sakep Sabancu Collection, Istanbul." Metropolitan Museum of Art. New York.

David, J. (1989). Calligraphy: The Geometry of the Script in Saudi Aramco World, 16-27. Sept/Oct

Etikan Sema (2011), The Principles of Ornament in Islamic art and effects of these Principles on the Turkich Carpet Art, Religion and Science Publications, 3(2), 87-95.

Fu, S., Lowry, G. D., \& Yonemura, A. (1986). "From concept to context”. Freer Gallery of Art, Smithsonian Institution; For sale by the Supt. of Docs., USGPO.

Faruqi, I. \& Lois L. (1986). “The Cultural Atlas of Islam”. American Journal of Islamic Social Sciences, 3(1), 169.

Fayeq, Oweis. (2002). Art as an Educational Tool about the Teacbing of Islam. Published by: National Art Education Assosiation. Stable, URL: https://www.jstor.org/stable/3193986. 
Ghulam, Yousif Mahmud. (1982). The Art Of Arabic Calligraphy. Lafayette, Ca. (P.O. Box 853, Lafayette 94549): Y.M. Ghulam.

Grabar, O. (1983). Reflections on the study of Islamic Art, Muqarnas, 1, 1-14.

Ghasemzadeh Behnam, Fathebaghali Atefeh (2013), Symbols and Signs in Islamic Architecture, European Review of Artistic Studies, 4 (3), 62-78.

Hossein Nasr Seyyed (1987), Islamic Art and Spirituality, State University of New York Press, Albany, NY.

Hossein Nasr Seyyed. (1968), Science; Civilization, Islamic; Science, Medieval; History; Islamic Empire, Cambridge: Harvard University Press.

Jafar, M. (2002). “Arabic Calligraphy: Naskh Script for Beginners”. British Museum Press.

Khatibi, Abdelkebir, and Mohamed Sijelmassi. (1996). The Splendor Of Islamic Calligrapby. New York: Thames and Hudson.

Khatibi, A. \& Sijelmassi, M. (1976). "The splendor of Islamic calligraphy”. Thames \& Hudson. London.

Khader, S. (2001). "The Qur'an manuscripts in the al-Haram al-Sharif Islamic Museum, Jerusalem." UK, Journal of Qur'anic Studies, 4(2), 88-90.

Minorsky, V. and Wheeler M. T. (1959). Calligraphers and Painters-A Treatise by Qadi Ahmad, son of Mir-Munshi. (circa AH 1015/AD 1606) Washington.

Modul, Seni Rupa. (1959). "The Meaning of Art". PDF, p.3 cited from Herbert Read, New York: Penguin Book.

Mortada, Hisham (2003) Traditional Islamic Principles of Built Environment. London: Curzon Publisher

M. Affandi, Ekspresi Simbolik, Religius dan Estetika dalam Karya Lukis Kaligrafi, (Yogyakarta: FPBS-IKIP, 1994), 135.

Massoudy, H., Nitzer, I. (1981), Calligraphie Arabe Vivante. Flammarion.Paris, 191.

Nasruddin, S. (2004). an Exbibition of Agfan Calligraphy and Miniature Painting. Dublin, Har Centre Library P.315.

Najda. (1994). “Arabic Calligraphy.” Women Concerned about the Middle East 94707th ser. (1994), 1-5.

Nasr, S. H. (1987). Islamic Art and spirituality. New York: State University of New York Pre.

Porter, Venetia, Isabelle Caussé, and British Museum. (2006). Word into Art: Artists of the Modern Middle East. London: British Museum Press.

Razwy, S. A. A. (2014). “A Restatement of the History of Islam and Muslims". Lulu Press, Inc. World Federation of KSI Muslim Communities United Kingdom.

Schimmel, Annemarie. (1990). Calligraphy and Islamic Culture. New York: New York University Press.

Schimmel, A. (1970). “Islamic Calligraphy”. Leiden: E.J. Brill Archive.

Schimmel, A. (1975). “Mystical Dimensions of Islam”. University of North Carolina press.

Sloman, Paul. (2009). Contemporary Art in the Middle East. London: Black Dog.

Siddiqua, S. (2011). Calligraphy - A Significant Islamic Heritage. http://www.imamreza.net/eng/imamrezaphp?accessed on 16th March 2013.

Saliu, B. A (2006). Aspects of Kano Cultural Tourism. (ed) in Perspective on Kano Volume I (ed) Uba, A.A and Ado, I.K, 1, 57-82. Telletters Consulting Coy Ltd 
Saliu, A.R (2013). Islamic Art for Peace and Unity: The Nigeria Initiative for National Integration. A paper presented at the opening ceremony of the $2^{\text {nd }}$ Islamic Arts/Calligraphy exhibition, held at conference hall National mosque, Abuja on14th September, 6.

Safadi, Y. H. (1978). "Islamic Calligraphy". London: Thames and Hudson.

Teparic, M. (2013). "Figural Representation in the Arabic Calligraphy." Epiphany Journal of Transdisciplinary Studies,. 6(2), 145-161. ISSN 1840-3719

Waterman, M. (2009). Itroduction to Arabic Calligraphy, 6.http://www.arabiccalligraphy.com, accessed on $31 / 01 / 2015$.

Yusuf, Qardhawi. (1998). Islam Bicara Seni, Translator. Wahid Ahmadi, M. Ghazali and Adhlan A. Hasyim, Solo: Intermedia

Zoghbi, Pascal. (2011). Graffiti Writer Stone, and Joy Hawley. Arabic graffiti. Berlin, Germany: From Here to Fame Pub.

Zakariya, M. (2002). A Brief Look at the History and Development of Arabic Calligraphy. http://www.zakariya.net/history/index.html. Accessed on 10th, October 2012. 